\title{
Serological and molecular testing in viral hepatitis: An update
}

\author{
Shiobhan R Weston MD, Paul Martin MD
}

SR Weston, P Martin. Serological and molecular testing in viral hepatitis: An update. Can J Gastroenterol 2001;15(3): 177-184. The routine serological diagnoses of the three major forms of viral hepatitis - A, B and C - as well as delta hepatitis, are important in the evaluation of acute and chronic viral hepatitis. Increasingly, molecular virology is also being used to evaluate patients with chronic hepatitis $\mathrm{C}$, with genotype and viral load testing to plan therapy.

Key Words: Hepatitis; Viral hepatitis

\section{Hépatite virale et tests sérologiques et moléculaires : mise à jour}

RÉSUMÉ : Les tests sérologiques usuels pour le diagnostic des trois grandes formes d'hépatite virale : $\mathrm{A}, \mathrm{B}$ et $\mathrm{C}$, ainsi que de l'hépatite delta jouent un rôle important dans l'évaluation de la maladie aiguë ou chronique. On recourt aussi de plus en plus à la virologie moléculaire pour évaluer les patients atteints d'hépatite $C$, de même qu'à l'étude du génotype et aux épreuves de charge virale pour planifier le traitement.
$T^{1}$ he three major forms of viral hepatitis encountered in North America - A, B and C - are now readily diagnosable by standard serological testing (1). However, there is increasing interest in more sophisticated diagnostic information, such as quantification of viral levels in chronic hepatitis $\mathrm{B}$ and $\mathrm{C}$ infection to guide treatment and genotyping of hepatitis C to assess interferon responsiveness. Diagnostic testing for hepatitis delta is also routinely available, and reference laboratories can provide hepatitis E testing. The purpose of this review is to provide an updated approach to the diagnostic evaluation of a patient with suspected viral hepatitis, incorporating newer information.

\section{HEPATITIS A}

Hepatitis A virus (HAV), a small RNA virus, enters into the differential of acute viral hepatitis only because it does not cause chronic liver disease $(1,2)$. Although HAV RNA testing is available as a research tool, the gold standard for the diagnosis of HAV infection is detection of immunoglobulin (Ig) M anti-HAV antibody, which is always present by the onset of clinical disease after an incubation period of three to six weeks. Typically, IgM anti-HAV persists for four to six months after infection, but on occasion, low titre antibody can be detected for many months. IgG antibody that is also present at onset of the clinical illness persists

This mini-review was prepared from a presentation made at the American Congress of Gastroenterology, Boston, Massachusetts, October 9 to 14, 1998

University of California at Los Angeles, and Cedars-Sinai Medical Center, Los Angeles, California, USA

Correspondence and reprints: Dr Paul Martin, Cedars-Sinai Medical Center, 8635 West 3rd Street, Suite 590W, Los Angeles, California 90048,

USA. Telephone 310-423-1971, fax 310-423-0234, e-mail martinpx@cshs.org

Received for publication September 16, 1999. Accepted September 27, 1999. Revised December 11, 2000 
indefinitely after recovery, and its presence denotes immunity, as a result of either prior infection or vaccination. Other methods of documenting HAV infection, including its recovery from stool or staining for hepatic HAV antigen, have no routine clinical application. Detection of $\operatorname{IgG}$ antiHAV in a patient with obvious chronic liver disease indicates that vaccination need not be offered to protect against the potentially serious consequences of superimposed HAV infection. The appropriate test to diagnose acute HAV infection is an IgM antibody test; 'total' anti-HAV does not distinguish IgM from IgG antibody and cannot provide confirmation that the infection is recent.

\section{HEPATITIS B}

Acute hepatitis B: The rather more complicated structure and lifecycle of the hepatitis B virus (HBV), a DNA virus, are reflected in the variety of tests available to detect infection, replication and immunity (1). Different HBV antigens - surface, core and e antigens - induce host antibody production and provide the major diagnostic tests for acute and chronic infection. The incubation period ranges from one to five months after infection to onset of symptoms. Hepatitis B surface antigen ( $\mathrm{HBsAg}$ ), which appears first within weeks of exposure, is indicative of infection. Its appearance is closely followed by that of hepatitis B e antigen $(\mathrm{HBeAg})$, the conventional marker of HBV replication, as well as other indicators of replication, most notably HBV DNA. Hepatitis B core antigen ( $\mathrm{HBcAg}$ ) does not circulate in serum but is demonstrated serologically by antibody directed against it (anti-HBc), which appears early in the course of infection before hepatic dysfunction or clinical illness. Initially, anti-HBc is an IgM antibody, which persists for about six months after infection. This is a nonneutralizing antibody, but its IgG fraction persists indefinitely. Indeed, the latter may be the sole marker of remote, resolved HBV infection because antibody to HBsAg (antiHBs), which is neutralizing and typically appears after clearance of $\mathrm{HBsAg}$, may ultimately disappear from serum many years after the resolution of HBV infection. Naturally acquired immunity to $\mathrm{HBV}$ is characterized by the presence of both anti-HBs and anti-HBc, whereas vaccine-induced immunity does not induce anti-HBc production.

Markers of replication, notably HBeAg and HBV DNA, are not useful for establishing the diagnosis of HBV infection - acute or chronic - but may provide useful prognostic information. Disappearance of HBeAg and HBV DNA during acute HBV infection implies decreasing viral replication and usually precedes clearance of $\mathrm{HBsAg}$, development of anti-HBs and resolution of infection. In contrast, persistence of $\mathrm{HBeAg}$ in serum for more than eight to 10 weeks after the acute illness is associated with the development of chronic infection. In chronically infected patients, progression to decompensated cirrhosis is predicted by ongoing active replication. Although clearance of $\mathrm{HBeAg}$ is typically followed by the appearance of antibody to $\mathrm{HBeAg}$ (anti-HBe), its development is not invariable, may not persist and adds little diagnostically. A variety of tests, qualita- tive and quantitative, are available for HBV DNA detection (3).

The most familiar quantitative technique is the Abbott assay (Abbott, USA), which uses molecular hybridization and is sensitive to $1.5 \mathrm{pg} / \mathrm{mL}$, corresponds to $4 \times 10^{5}$ genomes/mL. Other quantitative HBV DNA techniques include signal amplification capture (Digene Hybrid Capture Assay [Digene Corporation, USA]), branched DNA (bDNA) amplification assays (Quantiplex [Chiron, USA]) and polymerase chain reaction (PCR) assays (Cobas Amplicor HBV Monitor [Roche Diagnostic, USA]) (4). These tests use different standards, and it is not easy to compare results obtained by one method with another. However, reports comparing these three commercial techniques and an experimental 'slot blot' offer some useful information $(5,6)$. The bDNA assay was more sensitive than the Digene and Abbot assays. Furthermore, an HBV DNA level of less than $100 \mathrm{pg} / \mathrm{mL}$ by the Abbott assay corresponded to less than $1000 \mathrm{pg} / \mathrm{mL}$ by the Digene RNA DNA Hybrid assay and less than $4000 \mathrm{pg} / \mathrm{mL}$ by the Chiron bDNA assay. Clearly, it is crucial to ascertain the specific HBV DNA technique in use to interpret these quantitative results. One important application of HBV DNA testing has been determining the likelihood of interferon responsiveness in patients with chronic HBV infection; interferon therapy is generally futile, with serum HBV DNA levels higher than $200 \mathrm{pg} / \mathrm{mL}$, as determined by the Abbott method (7). PCR is several orders of magnitude more sensitive than other techniques for HBV DNA detection and may be positive when HBV DNA is otherwise undetectable (8-12). Titres measured by the manual Amplicor HBV Monitor test are approximately 2.5-fold and 30-fold lower than values obtained by the Digene and Quantiplex tests, respectively (8). This more sensitive Monitor assay makes it possible to assess more accurately the efficacy of antiviral therapy because many patients have viral loads that are detectable by PCR, but not by the less sensitive tests (10-12).

Diagnostic testing for HBV is complex because of its intricate lifecycle (Tables 1 and 2), and because of the variety of tests available and their limitations. HBsAg serologies are generally reliable, although occasional false positives have been reported, and false negative results may occur in resolving infection once serum $\mathrm{HBsAg}$ falls below detectable levels of 106 viral particles/mL. The simultaneous presence in serum of HBsAg and anti-HBs can occur during resolution of acute HBV before complete clearance of HBsAg (2). In chronic HBV infection, anti-HBs and $\mathrm{HBsAg}$ coexistence may be due to heterotypic antibody directed against $\mathrm{HBsAg}$ subdeterminants absent from the circulating HBsAg and the antibody is not neutralizing. Difficulties can also arise with interpretation of a positive $\mathrm{HBeAg}$ result in the absence of $\mathrm{HBsAg}$. This combination results from a false positive $\mathrm{HBeAg}$, which has been recognized in patients with rheumatoid factor positivity. Isolated anti-HBc can be found in a number of circumstances. In the 'window' period between clearance of $\mathrm{HBsAg}$ and the 
TABLE 1

Serology profiles in acute hepatitis B virus infection

\begin{tabular}{lccc}
\hline & HBsAg & Anti-IgM-HBc & Anti-HBs \\
\hline Acute & + & + & - \\
Recently resolved & - & + & \pm \\
\hline Anti-HBs Anti-hepatitis & $B$ & surface & antigen; Anti-lgM-HBC Anti- \\
immunoglobulin M hepatitis B core antigen; HBsAg Hepatitis B surface \\
antigen
\end{tabular}

appearance of anti-HBs, anti-HBc may be the only evidence of prior HBV infection. Detection of IgM anti-HBc confirms recent acute $\mathrm{HBV}$ infection. As noted above, anti-HBs may also decline to undetectable levels following resolution of $\mathrm{HBV}$ infection or may have never appeared. An amnestic response to $\mathrm{HBV}$ vaccine with anti-HBs formation occurs if the anti-HBc is not a laboratory error. The significance of anti-HBc as a marker of prior HBV infection is underlined by the frequent transmission of HBV to liver allograft recipients by organ donors who are serum $\mathrm{HBsAg}$ negative, who test anti-HBc positive. Presumably minute quantities of residual HBV in the donor organ, insufficient to produce detectable $\mathrm{HBs} \mathrm{Ag}$ in the immune competent host, begin to replicate actively as a result of therapeutic immune suppression in the HBV-naive recipient, producing clinical hepatitis. False positive anti-HBc seropositivity can also occur. Differentiation of HBV immunity, indicated by anti-HBs antibody, acquired naturally as a result of infection or induced by vaccine, is possible by anti-HBc testing, because the latter is only found in HBV infection. Although the presence of anti-HBs is usually protective against $\mathrm{HBV}$ infection, there are rare circumstances where acute HBV infection has been reported, suggesting a false positive antibody level or infection by an HBV strain not neutralized by anti-HBs. A low level of anti-HBs can reflect a false positive result or imply an inadequate level of protective antibody. It is helpful if the actual antibody level is reported. A level of less than $10 \mathrm{U}$ or radioimmunoassay ratio of less than 10 suggests the need for booster doses of $\mathrm{HBV}$ vaccine in a previously immunized subject or primary vaccination if tests for anti-HBc are negative (1).

Chronic hepatitis B: Less than 5\% of immune competent adults with acute HBV infection become chronically infected. Chronic infection is implied by the persistence of serum HBsAg for more than six months. Elderly people, children less than seven years of age and the immune compromised - for instance, due to renal failure - are most likely to remain persistently infected. Paradoxically, if acute HBV infection is clinically mild and anicteric, there is a higher probability of chronic infection, presumably due to a less vigorous immune response during initial infection. Typically, during the initial months and years of chronic infection, the markers of active viral replication, $\mathrm{HBeAg}$ and HBV DNA, are present. At a annual rate of $10 \%$ to $14 \%$, replication changes from high level to low level with the loss of HBeAg and typically improved liver chemistries. HBV DNA becomes undetectable by non-PCR methods
TABLE 2

Serology profiles in chronic hepatitis B virus (HBV) infection

\begin{tabular}{lccc}
\hline & HBsAg & Anti-IgM-HBc & Anti-HBs \\
\hline Resolved HBV infection & - & + & - \\
Chronic HBV with & & + & + \\
non-neutralizing anti-HBs & + & - & + \\
Vaccination & - & - \\
\hline
\end{tabular}

Anti-HBs Anti-hepatitis B surface antigen; Anti-IgM-HBC Antiimmunoglobulin $M$ hepatitis B core antigen; HBsAg Hepatitis B surface antigen

TABLE 3

Replication profiles in chronic hepatitis B virus (HBV) infection

\begin{tabular}{lccc}
\hline HBeAg & HBV DNA & Anti-HBe & Comment \\
\hline+ & + & - & Active replication \\
- & - & \pm & Inactive replication \\
- & + & \pm & Possible mutant \\
\pm & Increased & \pm & Possible escape mutant \\
& & & if occurs with nucleoside \\
& & & analogue therapy \\
\hline
\end{tabular}

Anti-HBe Anti-hepatitis B e antigen; HBeAg Hepatitis B e antigen

(Table 3). Often, this transition is heralded by a flare in disease activity, which may be misinterpreted as acute HBV, although IgM anti-HBc should be absent. In a long term follow-up of Asian-Americans with chronic HBV identified by a screening program in the Philadelphia area, spontaneous loss of $\mathrm{HBeAg}$ was most frequent if serum aminotransferase levels were elevated (13). Chronic HBV infection with normal alanine aminotransferase levels and the absence of $\mathrm{HBeAg}$ is colloquially referred as the 'healthy carrier state'. It usually implies a good long term prognosis, although clearly, if infection is long standing, progression to cirrhosis may have already occurred. Furthermore, reactivation of HBV can occur with reappearance of HBeAg in serum, even if anti-HBe is present. Reactivation is well recognized following chemotherapy but can also occur spontaneously without any obvious precipitant. It can be accompanied by a dramatic worsening of liver disease. Because IgM anti-HBc can reappear during reactivation of chronic $\mathrm{HBV}$, an antecedent history of infection is helpful to exclude de novo infection.

Mutant forms of HBV have attracted renewed interest over the past few years with the increasing use of nucleoside analogues (Table 2). 'Escape' mutants, which typically emerge after approximately eight months of therapy, are suggested by the reappearance of HBV DNA in serum and may be associated with increased hepatic dysfunction. Sequencing of the viral genome has identified a mutation in the DNA polymerase gene at the YMDD locus in 
TABLE 4

Diagnostic tests for hepatitis C virus (HCV) infection

\begin{tabular}{|c|c|c|}
\hline Tests & Uses & Comments \\
\hline $\begin{array}{l}\text { Anti-HCV } \\
\text { ELISA } 3.0\end{array}$ & Initial diagnosis & Excellent sensitivity \\
\hline \multirow[t]{2}{*}{ HCV RIBA 3.0} & Confirmatory test & $\begin{array}{l}\text { Used in low risk } \\
\text { populations for } \\
\text { confirmation of positive } \\
\text { ELISA }\end{array}$ \\
\hline & & $\begin{array}{l}\text { Highly predictive of } \mathrm{HCV} \\
\text { viremia in high risk } \\
\text { populations }\end{array}$ \\
\hline \multirow[t]{3}{*}{$\begin{array}{l}\text { HCV PCR } \\
\text { qualitative }\end{array}$} & $\begin{array}{l}\text { Confirmation of } \\
\mathrm{HCV} \text { infection }\end{array}$ & $\begin{array}{l}\text { May be helpful in } \\
\text { seronegative patients }\end{array}$ \\
\hline & & $\begin{array}{l}\text { Used for confirmation of } \\
\text { virological remission with } \\
\text { therapy }\end{array}$ \\
\hline & & $\begin{array}{l}\text { Used for early detection of } \\
\text { nonresponse to interferon } \\
\text { therapy }\end{array}$ \\
\hline \multirow[t]{3}{*}{$\begin{array}{l}\text { HCV PCR } \\
\text { quantitative }\end{array}$} & $\begin{array}{l}\text { Assessment of } \\
\text { viral load }\end{array}$ & $\begin{array}{l}\text { Less sensitive than } \\
\text { qualitative tests }\end{array}$ \\
\hline & & $\begin{array}{l}\text { More reproducible than } \\
\text { qualitative test }\end{array}$ \\
\hline & & $\begin{array}{l}\text { Role in predicting } \\
\text { interferon response } \\
\text { Used for monitoring viral } \\
\text { dynamics for early } \\
\text { indication of response to } \\
\text { therapy }\end{array}$ \\
\hline Genotype & $\begin{array}{l}\text { Treatment } \\
\text { decision }\end{array}$ & $\begin{array}{l}\text { Role in predicting } \\
\text { interferon responsiveness }\end{array}$ \\
\hline
\end{tabular}

PCR Polymerase chain reaction; RIBA Recombinant immunoblot assay

patients who had received lamivudine. Similar mutations also occur with other nucleoside analogues. A different mutation in the HBV $S$ gene has also been described in liver transplant recipients who developed recurrent HBV despite receiving high dose hepatitis B immune globulin prophylaxis involving the ' $\mathrm{a}$ ' determinant of this gene, which may impair the binding of hepatitis B immune globulin to HBV. The optimal management of therapy-related mutants remains to be determined (14). HBeAg-negative HBV mutants, which can produce clinically severe liver disease, have been identified (1).

\section{HEPATITIS C}

Serological diagnosis: Although identification of the hepatitis $\mathrm{C}$ virus (HCV) only occurred just over a decade ago, diagnostic testing has rapidly evolved from first generation serological testing to a variety of PCR methods and viral genotyping (Table 4) (15-17). However, in most clinical circumstances, the initial diagnostic workup is serological rather than molecular. The third-generation ELISA anti$\mathrm{HCV}$ has recently been introduced into clinical practice
(17). It differs from the second-generation test by incorporating an additional antigen from the nonstructural region (NS) 5 while retaining recombinant antigens (c22-3) from the core region, and NS3/NS4. As well as improving specificity, the third-generation test further shortens the interval to seroconversion in acute $\mathrm{HCV}$ infection. A major increase in the sensitivity of serological testing for chronic $\mathrm{HCV}$ occurred with the introduction of the second-generation ELISA test - an additional $20 \%$ of $\mathrm{HCV}$-viremic individuals who were found to be seronegative by the now obsolete first-generation antibody test were correctly identified as having HCV infection (17). The third-generation test will further reduce false negative ELISA tests when screening blood donors as well as patients with chronic liver disease, although to a much lesser extent than the introduction of the second-generation ELISA. A recent report suggests that individuals infected with genotype 1 have a significantly higher mean antibody response to the core and NS4 regions compared with those infected with other genotypes, reflecting the heightened HCV genotype sensitivity of the assay (18).

Because of the limitations of ELISA-based serologies, supplemental testing was developed to confirm the presence of HCV infection before the widespread availability of PCR. The recombinant immunoblot assay (RIBA) has been in clinical use in the United States for the past several years (17). This type of assay uses a nitrocellulose strip, coated with HCV antigens that react with $\mathrm{HCV}$ antibodies after incubation with patient sera. Antihuman goat IgG bound to horseradish-peroxidase is added, which is then stained. The colour intensity of the resultant bands reflects the amount of specific antibody bound. This is reported on a semiquantitative scale. Human IgG is incorporated as an internal control. Because HCV antigens are expressed as superoxide dismutase (SOD) fusion proteins, SOD is included in the strip to exclude nonspecific reactivity. A RIBA test is considered positive if two or more HCV antigen bands react at least as strongly as the human IgG-positive control and indeterminate if only one HCV band reacts. As with ELISA anti-HCV, there has been an evolution from a first-generation to a third-generation test. The latter incorporates $\mathrm{HCV}$ antigens from both the core and NS regions of the virus (17).

The major application of RIBA is in low risk individuals who test positive for anti-HCV on ELISA, such as blood donors (17). Using second-generation ELISA anti-HCV, less than $40 \%$ of seropositive donors are RIBA positive and another $20 \%$ to $40 \%$ are RIBA indeterminate. In low risk individuals, RIBA positivity is predictive of $\mathrm{HCV}$ viremia by PCR in $50 \%$ of cases; RIBA-indeterminate sera are viremic in a minority of cases. RIBA-negative sera are almost invariably PCR negative. However, failure of thirdgeneration RIBA to detect HCV core antibodies has been recently reported in a blood donor during seroconversion (19). Because it is widely accepted that core antibodies may be the only serological evidence during the early phase of HCV infection, this finding may have significant clinical 
implications and requires further evaluation. In RIBAindeterminate sera, ie, one reactive HCV band only, PCR positivity is most likely if the single positive band is either c22 (core region) or c33 (NS3 of the genome). Recent studies suggest that it may be more cost effective to use PCR instead of RIBA to confirm people found to be HCV positive on ELISA and to perform RIBA only if the PCR test is negative (19-22). Other supplemental tests include the matrix dot immunoassay and the line immunoassay $(14,23$ 25).

In patients with chronic liver disease, second-generation ELISA seropositivity is highly sensitive for HCV infection, in the order of $95 \%$ based on PCR as the gold standard (17). The newer third-generation ELISA increases sensitivity to $97 \%$. In a high risk population, supplemental testing with RIBA is usually positive, and in turn, RIBA positivity is highly predictive of HCV viremia by PCR. Supplemental testing with RIBA is probably not necessary unless there is concern about an alternate cause of liver disease associated with false positive anti-HCV, such as autoimmune hepatitis. It may be more appropriate to use PCR to confirm HCV as the cause of chronic liver disease, especially because evidence of active infection should be obtained before initiating antiviral therapy (24). Also, the level of viremia may influence the choice of treatment regimen (25). Immunecompromised subjects, including patients with end stage renal disease, can still have false negative HCV serologies, although the third-generation ELISA and RIBA tests should reduce the number of cases. The automated RIBA HCV strip immunoblot assay has most recently been shown to be a useful methodology for supplemental anti-HCV testing of specimens repeatedly reactive by ELISA (23).

Genotype-specific peptides have been studied with ELISA more recently to assess virus genotype based on the concept that HCV genotypes may show differences in immunogenicity. While the sensitivity of this method of genotype assessment may not be as high as that attained through PCR technology, it may be useful in the analysis of sera that are HCV negative by PCR techniques (26).

Despite the attempts of a number of groups to validate IgM anti-HCV antibodies that might help distinguish acute from chronic infection, no reproducible test has been introduced into clinical practice (27).

Molecular diagnosis: Although introduced originally as a research tool, PCR testing for HCV is widely available for routine diagnostic use (Table 4). A variety of techniques are in use, which occasionally makes it difficult to compare results obtained from one laboratory with those from another (15,28-31). However, there are two main types of PCR techniques - highly sensitive qualitative techniques and less exquisitely sensitive quantitative techniques. The most recent establishment of the international unit as a standard unit for measuring viral load will facilitate comparisons among tests in the future (32).

Qualitative methods generally rely on reverse transcription, in which RNA is first converted to complementary DNA, with subsequent identification of a nucleic acid sequence by a known oligonucleotide primer and generation of multiple copies using the polymerase reaction. Correct performance of this method, including careful specimen handling and avoidance of contamination, is crucial to obtain reproducible results. The Amplicor system developed by Roche Molecular Systems combines sensitivity with detection of as little as $100 \mathrm{HCV}$ RNA copies $/ \mathrm{mL}$, with excellent specificity in experienced hands (33).

Quantitative tests have become widely available to evaluate circulating HCV RNA levels - the so called viral load $(15,34,35)$. The bDNA test developed by Chiron depends on the capture of circulating HCV RNA by hybridization, with assessment of the quantity of RNA by chemiluminescent signal amplification $(35,36)$. The Amplicor HCV Monitor, also developed by Roche Molecular Systems, is a PCR-based method of HCV RNA quantification, with a cutoff of 1000 copies/mL (33,35-39). At first glance, the latter system would appear to be substantially more sensitive than the bDNA test, which is reported to have a cutoff of 200,000 genome Eq/mL (30-35). However, these two units were developed by their respective manufacturers in the absence of an accepted gold standard for HCV RNA measurement. Nevertheless, when the methods have been compared in untreated patients, differences in sensitivity have not been apparent, with HCV RNA readily detected by both methods because viral load is typically high in untreated patients, exceeding the limit of detection of the less sensitive bDNA test (37). In contrast, the sensitivity difference becomes apparent when testing patients who are on antiviral therapy, where the Amplicor HCV Monitor detects low viral loads in many patients who are found to be negative by the bDNA test (37-44). Sensitivity appears to be equivalent, with HCV RNA detected by both in about $90 \%$ of specimens viremic by qualitative PCR (45). Another frequently used quantitative PCR system has been developed by the National Genetics Institute in California (46). An important clinical correlate of viral load, which in untreated patients is relatively stable, has been the likelihood of durable interferon response (47-49). By using the bDNA test, a sustained response is more likely if pretreatment HCV RNA is less than $1 \times 10^{6}$ genomes $/ \mathrm{mL}$. By combining results from 652 patients in 11 studies, sustained response to interferon therapy was observed in $50.5 \%$ of patients with serum HCV RNA below this level, compared with only $17.3 \%$ with a higher viral load. However, the accuracy of low viral load in predicting a sustained response was only $68 \%$ (50). The issue of viral load as a predictor of interferon responsiveness will also be of interest once results of alternative treatment regimens with pegylated interferons and of combination therapy with ribavirin are studied further $(29,35,51,52)$. Another experimental application of HCV RNA testing is predicting a low likelihood of sustained response to interferon therapy if PCR remains positive after initial treatment $(46,53)$. Increasingly, end treatment responses and sustained responses in antiviral protocols are being defined by durable virological response rather than by biochemical surrogates such as alanine 
aminotransferase level due to superior accuracy of PCR negativity as a predictor of sustained response (54).

The most recent advancement in the quantification of the viral genome has been the development of real-time detection (RTD)-PCR based on the taqMan Chemistry system (Applied Biosystems, USA) (55). This assay consists of a dye-labelled oligonucleotide probe, primers complementary to the $5^{\prime}$ untranslated region of $\mathrm{HCV}$, recombinant Thermus thermophilus DNA polymerase and a sequence detector. Core DNA synthesis, and PCR amplification and analysis can be completed in a single reaction tube, without the false-positive results due to second-round amplification contamination associated with other assays. RTD-PCR can detect HCV RNA in patients found to be negative by the bDNA assay. RTD-PCR is reported to be 10 - to 100 -fold more sensitive than the Amplicor Monitor for detecting certain HCV genotypes, and overall has a much higher sensitivity in monitoring HCV viral loads in patients who are on alpha-interferon, but is not more sensitive than the qualitative Amplicor Version 2.0 test (Roche Diagnostic, USA) (55-57).

\section{HCV GENOTYPING}

The genetic heterogeneity of HCV has lead to the recognition of at least six distinct major genotypes of $\mathrm{HCV}$ as well as numerous subtypes, although there is an approximate $70 \%$ homology among all HCV isolates (34). A variety of methods have been used to determine genotype, both PCR and serological. Applications of HCV genotyping have included its use in epidemiological surveys of $\mathrm{HCV}$, as well as assessing interferon responsiveness and prognosis. The major $\mathrm{HCV}$ genotype worldwide ( $40 \%$ to $80 \%$ of isolates) is type 1 , with subtypes $1 \mathrm{a}$ and $1 \mathrm{~b}$ prevalent in the United States, whereas in other countries subtype 1a is less frequent. Type $2 \mathrm{a}$ is also found globally, accounting for a significant minority of infections. The other genotypes have more specific geographical associations. Type 3 is found in the Indian subcontinent, Thailand and Australia; type 4 in the Middle East and Africa; type 5 in South Africa; and type 6 in Hong Kong, Macau and Vietnam. Within a region, mode of transmission may be associated with a specific genotype; for instance, type 3 is common among Scottish intravenous drug users.

An unsettled issue is the impact of HCV genotype on disease progression and the development of complications such as hepatocellular carcinoma (58-60). Given the slow progression of $\mathrm{HCV}$, typically measured in decades, it would require a large prospective study to confirm the suggestion that infection with type $1 \mathrm{~b}$ is a predictor of an increased likelihood of developing decompensated cirrhosis and hepatocellular carcinoma, as suggested by some but not all cross-sectional or retrospective studies. In a large American transplant experience, the prevalence of HCV genotypes was similar to that of non-transplant patients with chronic $\mathrm{HCV}$, implying that genotype is not a predictor of progression to decompensated cirrhosis (61).
An important correlate of HCV genotype is, however, response to interferon monotherapy. Thus, sustained biochemical response was observed in 55\% of non-type 1 patients compared with only $18 \%$ of type $1 \mathrm{HCV}$ infection, when results of 15 studies that reported long term follow-up results were combined (50). Studies of longer term treatment and of combination therapy with ribavirin have highlighted the role of HCV genotype in predicting decreased responsiveness to interferon-based regimens $(13,62)$.

\section{DELTA HEPATITIS (HEPATITIS DELTA VIRUS)}

Because the RNA virus hepatitis delta virus (HDV) needs HBsAg to replicate, it is only found in patients with HBV infection (1). Acute HDV infection can be acquired simultaneously with $\mathrm{HBV}$ as a co-infection or as a superinfection in a patient with pre-existing HBV. With co-infection, the incubation period of HDV is similar to that of acute HBV infection. However, antibody to HDV can be slow to appear and transient, so if HDV is suspected in severe acute HBV infection or because of a history of intravenous drug use, repeated testing is indicated. Direct detection of HDV RNA and HDV antigens in serum is also available through some laboratories. IgM anti-HBc confirms that HDV infection is acute in co-infection because HBV infection will also be acute. Acute HDV superinfection is associated with durable anti-HDV production if infection becomes chronic and is suggested by the absence of IgM anti-HBc, because HBV infection is chronic. An IgM anti-HDV is also available through some laboratories to detect HDV early in the course of infection; this antibody declines in chronic HDV infection. In chronic HDV infection, markers of active HBV replication such as HBeAg and HBV DNA are generally absent, with detectable HDV RNA and HDV antigen, and a strongly positive anti-HDV antibody titre.

\section{HEPATITIS E}

Although hepatitis $\mathrm{E}$ is not indigenous to the United States, this important cause of enterically transmitted acute hepatitis has been recognized in travellers returning from abroad, with an incubation period of about six weeks. Diagnosis is based on the recovery of hepatitis E virus RNA from serum or stool. Serological diagnosis is also possible, although not widely available (63).

\section{CONCLUSIONS}

Despite the increasing sophistication of diagnostic techniques, the initial approach to the patient with suspected viral hepatitis is determined by the clinical impression of whether infection is acute or chronic (Tables 1 and 3). For suspected acute viral hepatitis, HAV and HBV remain the major differentials because acute HCV is usually subclinical, whereas HCV has become the major cause of chronic hepatitis. The appropriate uses of newer tests such as HCV RNA and genotype are currently being defined but will undoubtedly enhance management in the future. 


\section{REFERENCES}

1. Sjogren MH. Serological diagnosis of viral hepatitis.

Med Clin North Am 1996;80:929-56.

2. Martin P, Friedman LS, Dienstag JL. Diagnostic approach. In: Zuckerman AJ, Thomas HC, eds. Viral Hepatitis: Scientific Basis and Clinical Management. London: Churchill Livingston, 1993:393-410.

3. Leon R, de Medina M, Schiff ER. Diagnostic tools in the evaluations of patients with viral hepatitis undergoing liver transplantation. Liver Transpl Surg 1998;4:94-103.

4. Noborg U, Gusdal A, Pisa EK, Hedrum A, Lindh M. Automated quantitative analysis of hepatitis B virus DNA by using the Cobas Amplicor HBV monitor test. J Clin Microbiol 1999;37:2793-7.

5. Butterworth LA, Prior SL, Buda PJ, Faoagali JL, Cooksley WGE. Comparison of four methods for quantitative measurement of hepatitis B viral DNA. J Hepatol 1996;24:686-91.

6. Krajden M, Minor J, Cork L, Comanor L. Multi-measurement method comparison of three commercial hepatitis $B$ virus DNA quantification assays. J Viral Hepatol 1998;5:415-22.

7. Perrillo RP, Schiff ER, Davis GL, et al. A randomized, controlled trial of interferon alfa- $2 \mathrm{~b}$ alone and after prednisone withdrawal for the treatment of chronic hepatitis B. N Engl J Med 1990;323:295-301.

8. Pawlotsky JM, Bastie A, Hezode C, et al. Routine detection and quantification of hepatitis $\mathrm{B}$ virus DNA in clinical laboratories: performance of three commercial assays. J Virol Methods 2000;85:11-21.

9. Niesters HG, Krajden M, Cork L, et al. A multicenter study evaluation of the digene hybrid capture II signal amplification technique for detection of hepatitis B virus DNA in serum samples and testing of EUROHEP standards. J Clin Microbiol 2000;38:2150-5.

10. Hadziyannis SL, Manesis EK, Papakonstantinou A. Oral ganciclovir treatment in chronic hepatitis B virus infection: a pilot study. J Hepatol 1999;31:210-4.

11. Nagata I, Colucci G, Gregorio GV, et al. The role of HBV DNA quantitative PCR in monitoring the response to interferon treatment in chronic hepatitis B virus infection. J Hepatol 1999;30:965-9.

12. Gerken G, Gomes J, Lampertico P, et al. Clinical evaluation and applications of the Amplicor HBV Monitor test, a quantitative HBV DNA PCR assay. J Virol Methods 1998;74:155-65.

13. Evans AA, Fine M, London WT. Spontaneous seroconversion in hepatitis B e antigen-positive chronic hepatitis B: implications for interferon therapy. J Infect Dis 1997;176:845-50.

14. Locarnini SA. Hepatitis B virus surface antigen and polymerase gene variants: potential virological and clinical significance. Hepatology 1998;27:294-7.

15. Gretch DR. Diagnostic tests for hepatitis C. Hepatology 1997;26:43S-7S.

16. Lok AS, Gunaratnam NT. Diagnosis of hepatitis C. Hepatology 1997;26:48S-56S.

17. Younossi ZM, McHutchison JG. Serological tests for HCV infection. Viral Hepat Rev 1996;2:161-73.

18. Beld M, Penning M, van Putten M, et al. Quantitative antibody responses to structural (core) and nonstructural (NS3, NS4, and NS5) hepatitis $\mathrm{C}$ virus proteins among seroconverting injecting drug users: impact of epitope variation and relationship to detection of HCV RNA in blood. Hepatology 1999;29:1288-98.

19. Hennig H, Kirchner H, Kluter H. Failure of third-generation recombinant immunoblot assay to detect hepatitis $\mathrm{C}$ virus core antibodies. Transfusion 1999;39:335-6.

20. Schneeberger PM, Keur I, van der Vliet W, et al. Hepatitis C virus infections in dialysis centers in the Netherlands: A national survey by serological and molecular methods. J Clin Microbiol 1998;36:1711-5.

21. Mohan KV, Murugavel KG, Rajanikanth, et al. Diagnosis of hepatitis C virus infection by ELISA, RIBA, and RT-PCR: a comparative evaluation. Indian J Gastroenterol 1999;18:73-5.

22. Pawlotsky JM, Lonjon I, Hezode C, et al. What strategy should be used for diagnosis of hepatitis $\mathrm{C}$ virus infection in clinical laboratories? Hepatology 1998;27:1700-2.

23. Martin P, Fabrizi F, Dixit V, et al. Automated RIBA hepatitis $\mathrm{C}$ virus (HCV) strip immunoblot assay for reproducible HCV diagnosis. J Clin Microbiol 1998;36:387-90.

24. Dhumeaux D, Doeffoel M, Galmiche JP. A French consensus conference on hepatitis C: screening and treatment. J Hepatol 1997;27:941-4.
25. Poynard T, McHutchison J, Goodman Z, Ling MH, Albrecht J. The ALGOVIRC Project Group. Is an "a la carte" combination interferon-alfa-2b plus rebavirin regimen possible for the first line treatment in patients with chronic hepatitis C? Hepatology 2000;31:211-8.

26. Rodriguez-Lopez M, Rieza-boj JI, Ruiz M, et al. Immunogenicity of variable regions of hepatitis $C$ virus proteins: selection and modification of peptide epitopes to assess hepatitis $\mathrm{C}$ virus genotypes by ELISA. J Gen Virol 1999;80:727-38.

27. Tabone M, Secreto P, Marini C, et al. Pre-treatment levels of anti-HCV core IgM antibodies are closely associated with response to alpha interferon therapy in chronic hepatitis $C$ patients. J Gastroenterol Hepatol 1997;9:287-91.

28. Fang JWS, Albrecht JK, Jacobs S, Lau JYN. Quantification of serum hepatitis C virus RNA. Hepatology 1999;29:997-8.

29. Kobayashi M, Chayama K, Arase Y, et al. Predictive value of different hepatitis $\mathrm{C}$ serological assays in the treatment of chronic hepatitis $\mathrm{C}$ with interferon alpha. J Gastroenterol 1999;34:94-9.

30. Reichard O, Norkrans G, Fryden A, Braconier JH, Sonnerborg A, Weiland O. Comparison of 3 quantitative HCV RNA assays accuracy of baseline viral load to predict treatment outcome in chronic hepatitis C. Scand J Infect Dis 1998;30:441-6.

31. Trabaud MA, Bailly F, Si-Ahmed SN, et al. Comparison of HCV RNA assays for the detection and quantification of hepatitis $\mathrm{C}$ virus RNA levels in serum of patients with chronic hepatitis $\mathrm{C}$ treated with interferon. J Med Virol 1997;52:105-12.

32. Saldanha J, Lelie N, Heath A. Establishment of the first international standard for nucleic acid amplification technology (NAT) assays for HCV RNA. WHO Collaborative Study group. Vox Sang 1999;76:149-58.

33. Doglia A, Laffont C, Carolo-Bosc FX, Rochet P, LeFebvre JC. Second generation of the automated cobas amplicor $\mathrm{HCV}$ assay improves sensitivity of hepatitis C virus RNA. J Clin Microbiol 1999;37:1567-9.

34. Isaacson AH, Davis GL, Lau JYN. Should we test hepatitis C virus genotype and viremia level in patients with chronic hepatitis $\mathrm{C}$ ? J Viral Hepat 1997;4:285-91.

35. Lu RH, Hwang SJ, Chan CY, Chang FY, Lee SD. Quantitative measurement of serum HCV RNA in patient with chronic hepatitis C: comparison between amplicor HCV Monitor system and branched DNA signal amplification assay. J Clin Lab Anal 1998;12:121-5.

36. Kobayashi M, Kumada H, Arase Y, et al. Usefulness of hepatitis C virus RNA counts by second generation HCV bDNA-probe in chronic hepatitis $\mathrm{C}$ based on type HCV genotype. J Gastroenterol 1998;33:223-8.

37. Afonso AM, Didier J, Plouvier E, et al. Performance of an automated system for quantification of hepatitis $C$ virus RNA. J Virol Methods 2000;6:55-60.

38. Gerken G, Rothaar T, Rumi MG, et al. Performance of the COBAS AMPLICOR HCV MONITOR test, version 2.0, an automated reverse transcription-PCR quantitative system for hepatitis $\mathrm{C}$ virus load determination. J Clin Microbiol 2000;8:2210-4.

39. Martinot-Peignoux M, Boyer N, Le Breton V, et al. A new step toward standardization of serum hepatitis $\mathrm{C}$ virus-RNA quantification in patients with chronic hepatitis C. Hepatology 2000;31:726-9.

40. Ichijo T, Matsumoto A, Kobayshi M, Furihata K, Tanaka E. Quantitative measurement of HCV RNA in the serum: a comparison of three assays based on different principles. J Gastroenterol Hepatol 1997; 12:500-6.

41. Shiratori Y, Kato N, Yokosuka O, et al. Quantitative assays for hepatitis $\mathrm{C}$ virus in serum as predictors of the long-term response to interferon. J Hepatol 1997;27:437-44.

42. Pawlotsky JM, Martinot-Peignoux M, Poveda JD, et al. Quantification of hepatitis C virus RNA in serum by branched DNAbased signal amplification assays. J Virol Methods 1999;79:227-35.

43. Pensati P, Iorio R, Botta S, et al. Low virological response to interferon in children with chronic hepatitis C. J Hepatol 1999;31:604-11.

44. Hofgartner WT, Kant JA, Weck KE. Hepatitis C virus quantitation: optimization of strategies for detecting low-level viremia. J Clin Microbiol 2000;38:888-91.

45. Pawlotsky JM. Measuring hepatitis $\mathrm{C}$ viremia in clinical samples: Can we trust the assays? Hepatology 1997;26:1-4.

46. Tong MJ, Blatt LM, McHutchison JG, Co RL, Conrad A. Prediction of response during interferon alfa $2 \mathrm{~b}$ therapy in chronic hepatitis $\mathrm{C}$ patients using viral and biochemical characteristics: a comparison. Hepatology 1997;26:1640-5. 
47. Nguyen TT, Sedghi-Vaziri A, Wilkes LB, et al. Fluctuations in viral load (HCV RNA) are relatively insignificant in untreated patients with chronic HCV infection. J Viral Hepat 1996;3:75-8.

48. Ichijo T, Matsumoto A, Kobayashi M, Furihata K, Tanaka E. Quantitative measurement of HCV RNA in the serum: a comparison of three assays based on different principles. J Gastroenterol Hepatol 1997;12:500-6.

49. Hayashi J, Kawakami Y, Nabeshima A, et al. Comparison of HCV RNA levels by branched DNA probe assay and by competitive polymerase chain reaction to predict effectiveness of interferon treatment of patients with chronic hepatitis C virus. Dig Dis Sci 1998;43:384-91.

50. Davis GL, Lau JYN. Factors predictive of a beneficial response to therapy of hepatitis C. Hepatology 1997;26:122S-7S.

51. Gish RG. Future directions in the treatment of patients with chronic hepatitis C viral infection. Can J Gastroenterol 1999; 13:57-62

52. Williams CN. New treatment for hepatitis C. Can J Gastroenterol 1999;13:19-20.

53. Mathurin P, Moussalli J, Cadranel JF, et al. Slow progression rate of fibrosis in hepatitis $\mathrm{C}$ virus patients with persistently normal alanine transaminase activity. Hepatology 1998;27:868-72.

54. Civeira MP, Prieto J. Early predictors of response to treatment in patients with chronic hepatitis C. J Hepatol 1999;31:237-43.

55. Takeuchi T, Katsume A, Tanaka T, et al. Real-time detection system for quantification of hepatitis $\mathrm{C}$ virus genome. Gastroenterology $1999 ; 116: 636-42$.
56. Martell M, Gomez J, Esteban JI, et al. High-throughput real-time reverse transcription-PCR quantitation of hepatitis $\mathrm{C}$ virus RNA. J Clin Microbiol 1999;37:327-32.

57. Mercier B, Burlot L, Ferec C. Simultaneous screening for HBV DNA and HCV RNA genomes in blood donations using a novel TaqMan PCR assay. J Virol Methods 1999;77:1-9.

58. Murakami C, Hino K, Korenaga M, et al. Factors predicting progression to cirrhosis and hepatocellular carcinoma in patients with transfusion-associated hepatitis $\mathrm{C}$ virus infection. J Clin Gastroenterol 1999;28:148-52.

59. Zien N, Poterucha JJ, Wiesner RH, et al. Hepatocellular carcinoma in patients infected with different hepatitis C genotypes. Gastroenterology 1995;108(Suppl 1):A1207. (Abst)

60. Takada A, Tsutsumi M, Zhang SC, et al. Relationship between hepatocellular carcinoma and subtypes of hepatitis C virus: a nationwide analysis. J Gastroenterol Hepatol 1996;11:166-9.

61. Zhou S, Terrault NA, Ferrell L, et al. Severity of liver disease in liver transplant recipients with hepatitis $\mathrm{C}$ virus infection: Relationship to genotypes and level of viremia. Hepatology 1996;24:1041-6.

62. McHutchinson JG, Gordon SC, Schiff ER, et al. Interferon alfa-2b alone or in combination with ribavirin as initial treatment for chronic hepatitis C. N Engl J Med 1999;339:1485-92.

63. Mast EE, Alter MJ, Holland PV, et al. Evaluation of assays for antibody to hepatitis $\mathrm{E}$ virus by a serum panel. Hepatology 1998;27:857-61. 


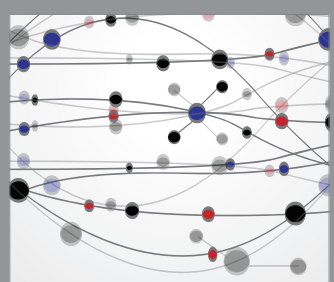

The Scientific World Journal
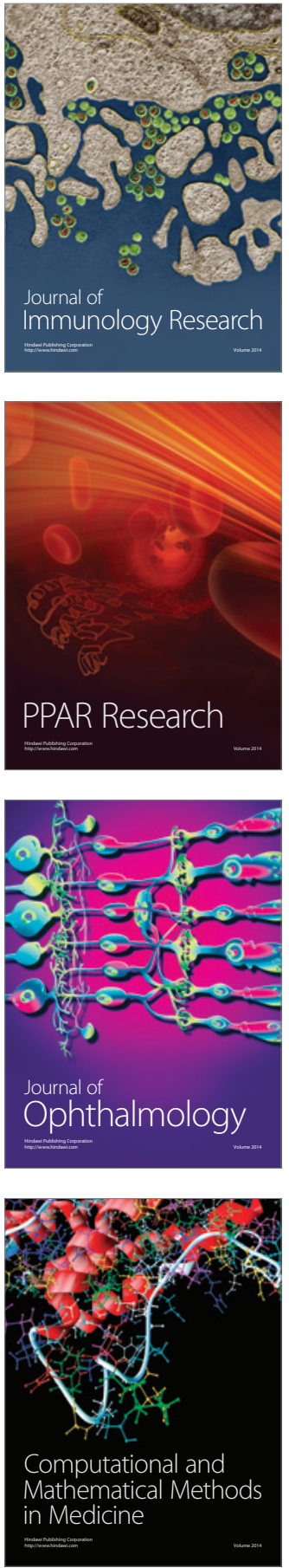

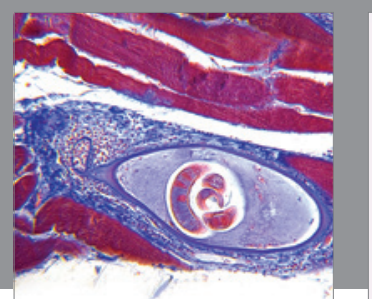

Gastroenterology Research and Practice

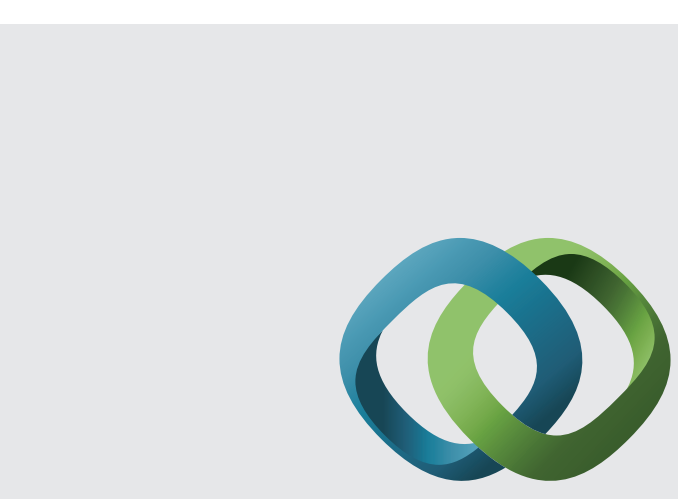

\section{Hindawi}

Submit your manuscripts at

http://www.hindawi.com
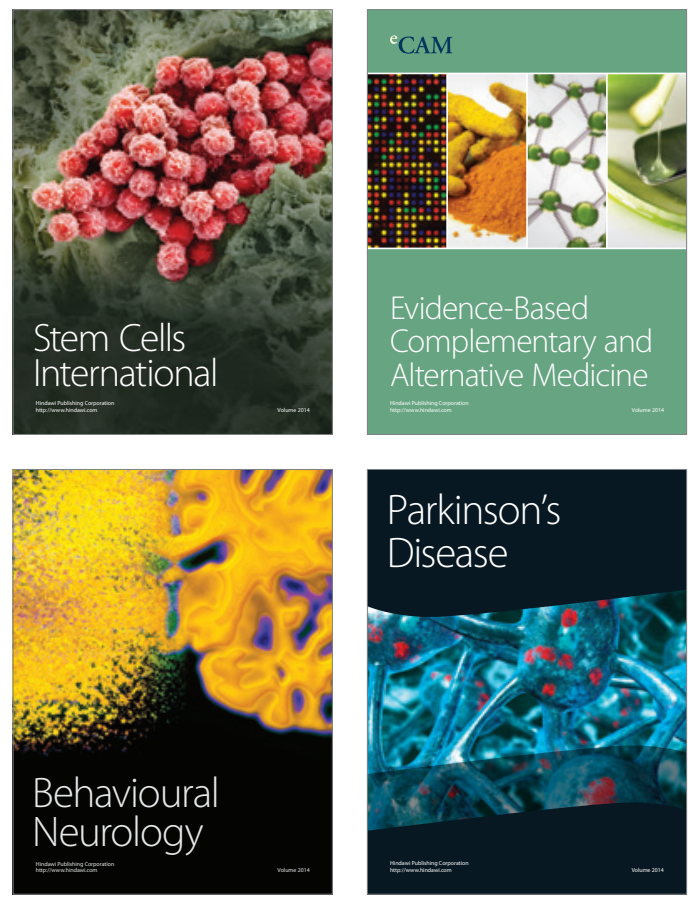
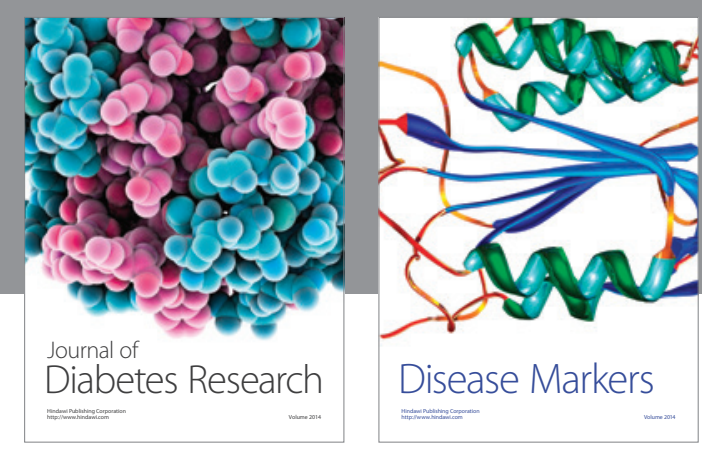

Disease Markers
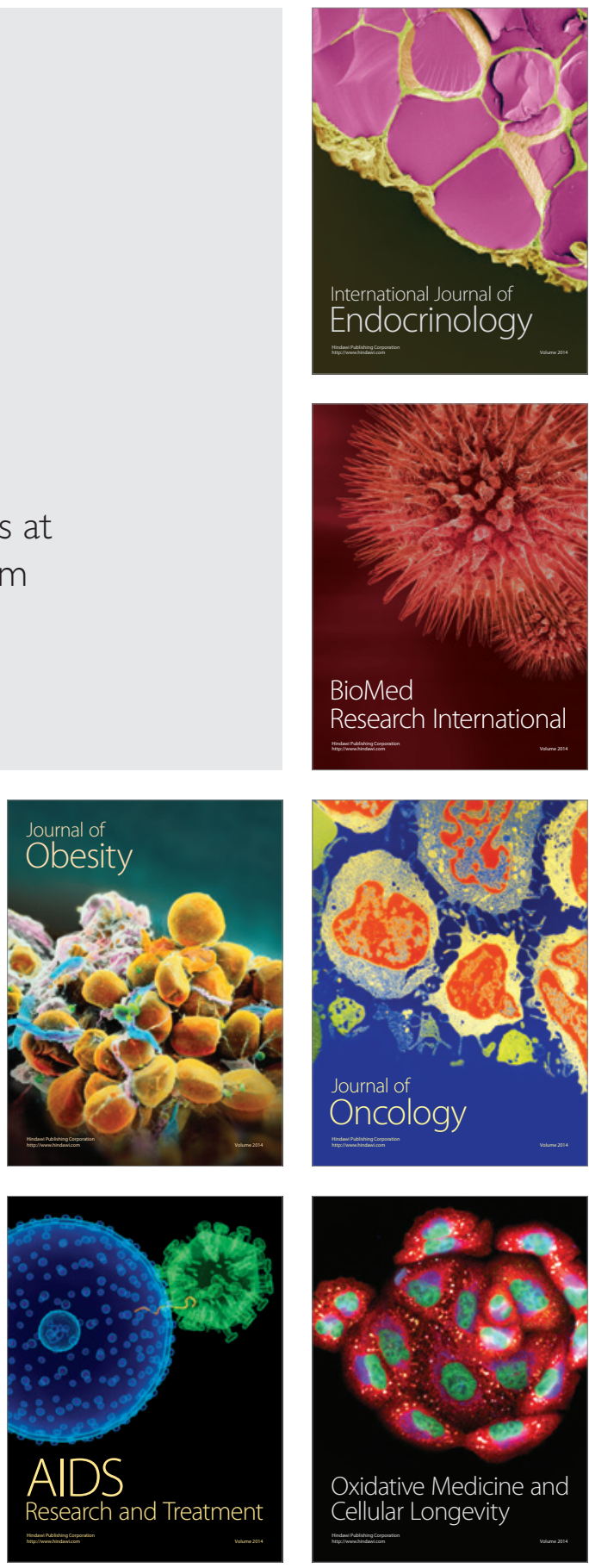